\title{
Effect of NPK and Actosol on the Growth, Essential Oil Production and Biochemical Composition of Zanthoxylum piperitum Plant.
}

\author{
Esmail S. E. A ${ }^{1}$, A. A. M. Heikal ${ }^{1}$ and A. A. Nassrallah ${ }^{2}$ \\ ${ }^{1}$ Ornamental Horticulture Department, Faculty of Agriculture, Cairo University, Giza, Egypt. \\ ${ }^{2}$ Biochemistry Department, Faculty of Agriculture, Cairo university, Giza, Egypt.
}

Received on: 29-6-2021

Accepted on: 26-9-2021

\begin{abstract}
A pot experiment was carried out to study the effects of NPK and Actosol on plant growth, essential oil, chemical composition and antioxidantactivity of Zanthoxylumpiperitum plant, it was conducted under in saran greenhouse, at the Experimental Nursery of the Ornamental Horticulture Depart., Fac., of Agric. ,Cairo Univ., during 2018/20192019/2020.The plants were fertilized with NPK at 12g/plant (100\% recommended dose), 9 and $6 \mathrm{~g} / \mathrm{plant}$,s prayed with Actosol at $0,1.5$ and $2.5 \mathrm{ml} / \mathrm{L}$. Treating plants with 6 and $9 \mathrm{~g} / \mathrm{plant} \mathrm{NPK}+$ Actosol at $2.5 \mathrm{ml} / \mathrm{L}$, gave tallest plants , highest No. of branches and significantly increased the fresh and dry weights of plants, in both seasons. Reducing NPK from 12 to 9 or $6 \mathrm{~g} / \mathrm{plant}$ increased significantly essential oil $\%$, and had a positive effect in both seasons. Actosol at $1.5 \mathrm{ml} / \mathrm{L}$ gave the highest oil \%,while at $2.5 \mathrm{ml} / 1$ gave the highest oil yield /plant. Twenty compounds were identified by GC-MS ( $\beta$ phellandrene, cyclohexanol, germacrene-D, $\alpha$-pinene, geranyl acetate and 1,8-cineole), were the dominant compounds, which increased with NPK (12,9 and $6 \mathrm{~g} / \mathrm{plant})+$ Actosol $1.5 \mathrm{ml} / \mathrm{L}$, in the first seas on, res pectively. Decreasing NPK doses combined with high rate of Actosol increased the phenolic contents. The highest flavonoids content was recorded in plants treated with NPK 9g/plant + Actosol $1.5 \mathrm{ml} / \mathrm{L}$ (first seas on) and NPK $9 \mathrm{~g} / \mathrm{plant}$ (second one). The antioxidant profile indicated that the crude extract in plants received 12g/plant NPK showed the highest IC50 in both seasons.
\end{abstract}

KEYWORDS: Zanthoxylum piperitum, Korean pepper, NPK, Actosol , Essential oil and Antioxidant

\section{INTRODUCTION}

The genus of Zanthoxylum (family Rutaceae) comprises about 250 species, native to the temperate and subtropical regions of the world. It include an important group of plants which has much commercial and ethanobotanical importance, used as sources of pharmaceutical and cosmetics raw material. Okagu et al., (2021) stated that many of the plant species are used as food ingredients. One of the most important species is Z. piperitum (Japanese pepper or Korean pepper), it is an aromatic spiny shrub (Ravindran 2017), native to Japanese, China and Korean . It has special aroma(all plant organs), is used as a spice, and employed in the traditional medicine, and as a vegetable (Imaizumi 1999 and Hashimoto et al., 2001).

The essential oils of Zanthoxylum piperitum show a strong antimicrobial, insecticidal, antioxidant and anticancer activities (Kamsuk et al., 2007and Lee and Lim 2008), as well as show a wide spectrum of biological activities (as anti-inflammatory, analgesic, antinocic eptive, antibiotic, hepatoprotective, antiviral and antifungal due to the constituents, essential oil, alkaloids and cumarins (Kim et al., 2003 and Negi et al., 2011,the fruit extract has strong antioxidant (Yamazaki et al., 2006).

Fertilization of NPK is one of the most important factors limiting the productivity of plants. It is the most striking practice in the plant nutrition (Marschner,2012). Nitrogen $(\mathrm{N})$ is required in synthesis of proteins and enzymes, it is a component of amino acids, nucleic acids and chlorophyll . Phosphorus (P) is one of the most macro nutrients, it plays a vital role in growth and root development. ( $\mathrm{Jin}$ et al., 2005, Marschner,2012 and He et al., 2019). Sharpley et al., (1996) mentioned that $\mathrm{P}$ has the role of storage and transfer of energy through the plant (ADP\& ATP) that control the processes of photosynthesis, respiration, protein and nucleic acid synthesis, and nutrient transport in plant cells. Potassium $(\mathrm{K})$ is the most abundant cation in higher plants, it has pivotal role in plant physiology and enzymatic activity (Khalid and Shedeed 2015 and Hasan et al., 2016).It is involved in plant cell membrane, regulation of stomata, maintenance of turgor, and enzyme activity (Wiedenhoeft, 


\section{Scientific Journal of Agricultural Sciences 3 (2): 13-29, 2021}

2006).Hosseini (2012) reviewed the promoting roles of $\mathrm{N}, \mathrm{P}$ and $\mathrm{K}$ on production of some important medicinal plants (basil, turmeric, black pepper, cardamom, fennel, fenugreek and aloe)..

Actosol is biostimulant, formulated with natural substances(20\% humic and fulvic acids), it derived from leonardite (natural humus), it improves stress tolerance, water retention, enhances chelating of nutrients and root and plant growth. Several authors explained the positive effect of Actosol and other humic products, in improving the productivity of plants. In addition, Masciandaro et al., (2002) confirmed its role in enhancing the uptake of nutrients, cell membrane permeability, oxygen uptake, respiration, photosynthesis and cell elongation. The major functional groups include carboxyl, phenolic hydroxyl, alcoholic hydroxyl and ketone that has a positive effect on plant growth and the nutrient uptake (Cacco and Agnolla,1984). Pouneva (2005) and Burkowska and Donderski (2007) reported that humic substances increased the growth rate by stimulating enzyme activities. EL-Gohary et al., (2014) on Mentha piperita found that essential oil\% and constituents increased with foliar nutrition of humic acid. Auimoviu et al., (2015) found that bio-humus (Royal Ofert) significantly increased the oil\% in anise. ElSherif and Ismail (2017) stated that humic acid at 2g/1 increased the growth, yield and curcumin \%. On achillea Sani and Jodaeian (2017) and on Thymus kotschyanus ,Saber et al., (2021) obtained similar results.

Many studies investigated the possibility of biofertilizers utilization instead of mineral fertilizersNPK and their effects on growth, oil yield and secondary metabolites, as previously reported by Mohamed and El-Ganaini (2003), Badran and Safwat (2004) on fennel plant and Swaefy et al., 2007) on peppermint plant. Also, Abdelaziz et al., (2007) indicated that biofertilizers could replace the conventional NPK fertilizers of rosemary ,they obtained a significant increase in growth, carbohydrate content and essential oil production. On fennel, Azzaz et al., (2009) and Valiki and Ghanbari (2015) emphasized the possibility and enhancing effect of organic and bio-fertilizers utilization instead of NPK on vegetative growth and oils yield, giving significant increases growth and oil yield. Hassan et al., (2015) on basil stated that NPK at $100 \%$ of recommended and

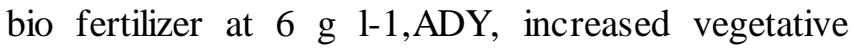
growth ,total chlorophyll, oil\% and linalool. Ahmed (2017) on celery and dill plants, revealed bio fertilizer $+50 \%$ NPK significantly increased vegetative growth,chlorophylls and essential oils\% as well the main components( $\beta$. pinene, limonene and $B$ phellandrene\%). Shehata (2019) on parsley recommended $200 \mathrm{mg} / \mathrm{l}$ humic acid $+50 \%$ of recommended NPK for growth and chlorophyll content. Ghatas (2020) indicated that different treatments of NPK and bio-fertilization significantly increased chemical constituents and oil productivity.

Ahmed et al., (2019) on chamomile plant stated that NPK alone increased vegetative growth and NBK+ bio-fertilizer significantly increased volatile oil\%. ElSayed et al., (2021) on Camelina sativa found that $100 \%$ NPK and $75 \%$ NPK + Bio produced the highest values of vegetative growth, chemical composition and oil productivity.

Therefore, the aim of present study was to investigate the effect different doses of NPK and Actosol as foliar application at different rates on the growth, essential oil production and biochemical composition of Japanese pepper Zanthoxylum piperitum. plant.

\section{MATERIALS AND METHODS}

\subsection{Procedures and design}

A pot experiment was conducted at the Experimental Nursery of Ornamental Horticulture Depart.,Fac. of Agric. ,Cairo Univ.,Giza (30E01' 39.36" N latitude and31E12' 36.50"E Longitude) during the seasons of 2018/19 and 2019/20 to study the effect of NPK fertilization and Actosol on growth, essential oil (EO) content and (EO)composition, as well as and chemical composition of Zanthoxylum piperitum. plant. On May 27th, 2018 and May 30th, 2019 during the first and second seasons, respectively, the age of 6 months uniform seedlings $(20-25 \mathrm{~cm}$ height-from private nursery) were individually transplanted into $40 \mathrm{~cm}$ plastic pots filled with loamy clay soil Table (1). The experiment was conducted under partial shade conditions in saran house $(50 \%$ shade). The experimental design was randomized complete block design in split plot form with three replicates. The three levels of NPK (12 g/plant as 100 $\%$ addition, $9 \mathrm{~g} /$ plant as $75 \%$ and 6 g/plant as 50\%) were allocated to the main plots, while the three concentrations of Actosol ( $0,1.5$ and $2.5 \mathrm{ml} / \mathrm{L})$ were assigned as sub plots. Each level of sub plot was represented by five pots for each replicate. Each level of NPK was applied as a soil drenching at three equal splits; one, three and five months after transplanting, respectively, whereas, Actosol was bimonthly applied as foliar application four times; starting after a week from transplanting and spraying plants with Actosol was carried out up to run off point. Actosol was obtained from Egy-American Co.For Investment \& 
Table 1. The physical and chemical analysis of the experimental soil during the two seasons.

\begin{tabular}{llccccc}
\hline & $\mathbf{p H}$ & $\mathbf{E C}$ & Organic Matter & $\mathbf{N}$ & $\mathbf{P}$ & $\mathbf{K}$ \\
& & $\mathrm{dS} / \mathrm{m}$ & $\mathbf{\%}$ & & $\mathbf{p p m}$ & \\
\hline First season & 7.60 & 1.42 & 1.35 & 19.42 & 11.25 & 122 \\
Second season & 7.32 & 1.58 & 1.42 & 21.75 & 13.15 & 131 \\
\hline
\end{tabular}

pH: Soil acidity; EC: Electrical conductivity; N: Nitrogen; P: phosphorous; K: potas sium.

Agriculture Devel. Heliopolis, Cairo. Spraying with tap water represented the control treatment. The plants were irrigated regularly.

\subsection{Recorded Data:}

In this study, we focused on the chemical and physiological responses of Z . piperitum to NPK and Actosol supplements. After 6 months of treatments, the following morphological measurements were determined: The data on the grow th parameters were recorded on mid-May in 2019 and 2020 , in terms of plant height, stem diameter ,No. of branches/ plant, root length and roots No/plant, leaves, stem, and roots fresh weight/plant were determined at harvest of each season. The fresh leaves, stems and roots were dried at $70 \mathrm{C}^{\circ}$ for $48 \mathrm{hr}$. and the dry weights were recorded.

\subsection{Essential oil extraction and GC-MS analysis:}

The essential oil (EO)in the air dried leaves was obtained by hydro-distillation using the original Clevenger-type apparatus for EO, lighter than water (according to British Pharmacopoeia,(1963).Samples of leaves $(100 \mathrm{~g})$ were used to determine the EO \% $(\mathrm{v} / \mathrm{w})$. The obtained oil was separated by extraction with Et2O (Merck, Germany), maintained dry by subjecting samples to anhydrous sodium sulfate

( Na2SO4, Aldrich, USA), and immediately analyzed. To determine the main constituents of the obtained EO, GC/MS analysis was performed according to Adams (1995) at the Central Laboratory of Fac.of Agric., Cairo Univ. The retention time (RT) of the components was used to identify the constituents of the EO and the report of GC/MS analysis, helped in calculation the of main components percentage of essential oil.

\subsection{Total chlorophylls content:}

It was determined using a digital chlorophyll meter $(\mathrm{SPAD})$, model SPAD-502, which SPAD unit = $10 \mathrm{mg} / 100 \mathrm{~g}$ fresh weight of leaves (Netto et al., 2005).

\subsection{Total hydrolysable carbohydrate:}

Samples of $0.5 \mathrm{~g}$ from dried ground leaves were placed in $20 \mathrm{ml}$ test tubes, followed by addition of
$10 \mathrm{ml} 1 \mathrm{~N}$ sulfuric acid. The tube was sealed, and placed overnight in an oven at $100^{\circ} \mathrm{C}$, then it was completed $100 \mathrm{ml}$ with distilled water and filtered. The total hydrolysable carbohydrates were determined using the phenol- sulfuric acid method according to Dubois et al. (1956).

\subsection{Determination of total phenol and flavonoids contents:}

Polyphenolics contents were determined by the Folin-Ciocalteu method (Meda et al., 2005). Flavonoids content was determined in each extract according to the aluminum chloride colorimetric method described by Chang et al., (2002).

\subsection{Antioxidant activity:}

Total free radical scavenging capacity of the extract was evaluated by two different metheds using the stable 2,2-diphenyl-1-picrylhydrazyl (DPPH) radical as reported by Kedare and Singh, (2011).

\subsection{Determination of $N, P$ and $K$ contents:}

The digested solution was chemically analyzed to determine the concentration of N, P and $\mathrm{K}$ in the dry leaves according to the method recommended by Cottenie et al (1982). N-content was determined by the modified micro-Kjeldahl method as described by A. O. A. C (1990), P-content according to Jackson (1973) and $\mathrm{K}$ - content by using atomic absorption spectrophotometer Model SP 1900 with a boiling airacetylene burner and recorded read out Issac and Kerber (1971).

\subsection{Statistical analysis:}

Data recorded on the growth parameters were subjected to analysis of variance based on split-plot arrangement in a randomized complete block design according to procedures outlined by Gomez and Gomez (1984) using MSTAT-C computer package Freed et al., (1989). Treatment mean comparisons were performed using least significant difference (LSD) at $5 \%$ level of probability. 


\section{Scientific Journal of Agricultural Sciences 3 (2): 13-29, 2021}

\section{RESULTS AND DISCUSSION}

\subsection{Morphological Responses :}

Data obtained on the morphological responses of Zanthoxylum piperitum plants to the application of NPK and Actosol, Table( 2) revealed that treating plants with low and medium levels of NPK (6 and 9 $\mathrm{g} /$ plant ) signific antly affected plant height, comparing to the low one. The dose of $6 \mathrm{~g} / \mathrm{plant}$ gave the tallest plants $(43.50$ and $45.42 \mathrm{~cm})$, in the first and second seasons, respectively. Under the treatment of Actosol, the high level $(2.5 \mathrm{ml} / \mathrm{L})$ gave the tallest plants $(45.92-$ $47.58 \mathrm{~cm}$ ) in both seasons, respectively. The combined treatment of NPK at $6 \mathrm{~g} /$ plant with Actosol at $2.5 \mathrm{ml} / 1$, gave the tallest plants, giving 50.25 and $51.0 \mathrm{~cm}$, in the first and second seasons respectively. The results proved that the lowest level of NPK $(6 \mathrm{~g} / \mathrm{plant})$ tended to promote the height growth in the presence of Actosol.

The response of stem diameter to NPK and Actosol (Table 2) shows that stem thickness of plants treated with NPK $6 \mathrm{~g} / \mathrm{plant}$, regardless the effect of Actosol, had the highest values $(0.98$ and $0.83 \mathrm{~cm})$, in the first and second seasons, respectively. Spraying plants with Actosol at high level $(2.5 \mathrm{ml} / \mathrm{l})$ was the most effective in increasing it in both seasons.

Treating the plants with NPK at $6 \mathrm{~g} /$ plant gave the greatest No. of branches /plant (12.75 and 13.83) in both seasons, as compared to the other NPK doses( Table 2). Regardless, the effect of NPK, spraying $Z$. piperitum plants with Actosol at $2.5 \mathrm{ml} / 1$ produced the highest No. of braches/plant(13.83and14.83, in both seasons, respectively). The combination between NPK $6 \mathrm{~g} /$ plant + Actosol $2.5 \mathrm{ml} / \mathrm{L}$ recorded the highest N0.of branches /plant (15.50 and16.75) in the two seasons, respectively, followed by the treatments of NPK 6g/plant + Actosol 1.5 and NPK 9 g/plant + Actosol $2.5 \mathrm{ml} / \mathrm{l}$. Whereas, the treatment of NPK (6g/plant) without Actosol sprayings, resulted in the lowest No. of branches/plant (8.75 and 9.50) in both seasons. This means that the foliar spraying of Actosol enhancing the formation of branches. Regarding the responses of root length and roots $\mathrm{No} /$ plant to the treatments of NPK and Actosol, as shown in Table(2) the data revealed that NPK at 9g/plant ,regardless Actosol treatments, insignificantly increase the root length $(46.25$ and $48.08 \mathrm{~cm})$, over the other two doses ,in both seasons. But, Actosol $2.5 \mathrm{ml} / 1$ significantly increased it $(50.83$ and $52.50 \mathrm{~cm}$, respectively) as compared with the control.

The interaction between NPK and Actosol had a signific ant effect in the $2^{\text {nd }}$ season, and plants treated with $6 \mathrm{~g} /$ plant $\mathrm{NPK}+2.5 \mathrm{ml} / \mathrm{L}$ Actosol gave the tallest roots (53.75and $55.00 \mathrm{~cm}$ ) in the two seasons, respectively. The same Table.(2) shows that the No.of roots in plants treated with NPK at $6 \mathrm{~g} /$ plant was significantly more than that of NPK at 9 and 12 $\mathrm{g} / \mathrm{plant}$, only in the $2^{\text {nd }}$ season, giving the greatest number of main roots /plant (4.33 and 4.92). Actosol at $2.5 \mathrm{ml} / \mathrm{L}$, in both seasons, gave the greatest number of main roots /plant (5.75).

The stimulation effects of applying NPK on vegetative grow th may be attributed to the well known functions of N,P and K, which they are the most abundantly acquired mineral elements by plants, they play vital roles in many aspects of plant metabolism and plant life. NPK-fertilization is one of the most important factors limiting plant productivity(Jin et al., 2005, Marschner,2012 and $\mathrm{He}$ et al., 2019), as mentioned in Introduction. The sufficient supply of these macro-elements is required for their proper functions on activation of photosynthesis and metabolic processes of organic compounds in plants , consequently, the vegetative growth parameters increased. These findings are in agreement with results recorded by Hosseini (2012) on some economic medicinal plants (basil, turmeric, black pepper, cardamom, fennel, fenugreek and aloe), Khalid and Shedeed (2015) on Nigella sativa plant.

Concerning the responses of fresh and dry weights of leaves and stems to the application of NPK and Actosol as shown in Table (3), it is obvious from the obtained data show that the application of $6 \mathrm{~g} / \mathrm{plant}$ NPK alone gave the least values for fresh and dry weights of leaves and stems. Raising the NPK rate from 6.0 to 9.0 and $12.0 \mathrm{~g} / \mathrm{plant}$ gradually increased the fresh and dry weights of leaves and stems. Also, raising the Actosol rate from 1.5 to $2.5 \mathrm{ml} / 1$ significantly increased the fresh and dry weights, recording the heaviest weights in both seasons. Regarding the combined treatments of NPK with Actosol, the data cleared that the application of $6 \mathrm{~g} /$ plant of NPK + spraying plants with Actosol at 2.5 $\mathrm{ml} / \mathrm{l}$, were the most effective in increasing the fresh and dry weights of both leaves and stems, in both seasons. Moreover, the treatments of Actosol at $2.5 \mathrm{ml} / 1$ under NPK at $9 \mathrm{~g} / \mathrm{plant}$ resulted in higher increases than those obtained under NPK at 6 $\mathrm{g} /$ plant, as compared with other treatments.

The fresh and dry weights of roots/plant, in response to NPK and Actosol treatments, had a similar trend to the responses of root length and number/plant, obtaining the heaviest weights with the treatment of $6 \mathrm{~g}$ /plant NPK combined with $2.5 \mathrm{ml}$ Actosol spraying, in both seasons. These results are in harmony with that obtained by Chen and Avaid (1990) they reported that 
Esmail S.E.A et al., 2021

Table 2. Effect of NPK and Actosol and their interactions on plant height, stem diameter, branches No./plant ,root length and roots No/plant of Zanthoxylum piperitum plant during 2019and 2020seasons.

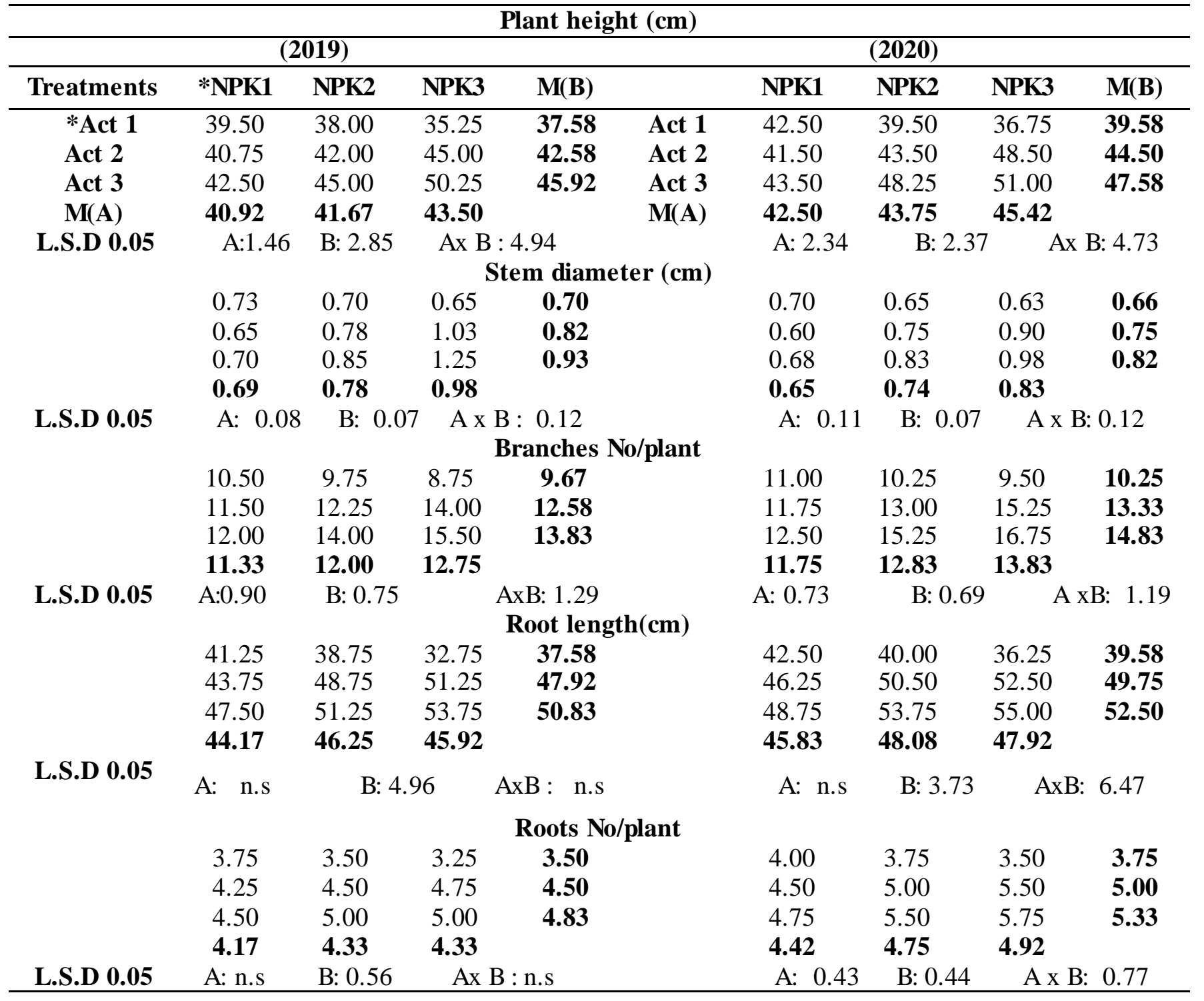

humic substances had a very pronounced influence on the grow th of roots and enhanced root initiation. Also, Hanafy et al., (2017) on Artemisia abrotanum who explained that Actosol affected on the cells elongation as will formation of new tissues more that the effected of NPK. Samavatipour et al., (2019) on Anethum graveolens stated that root fresh and dry weights of plants treated with fulvic acids was higher than the control, improving the root system, consequently allowed for nutrients and minerals to be absorbed readily. Nofal et al., (2020) Erantheumum pulchellum found that application of NPK and humic acid gave the best results than the control.
From the above mentioned results, treating plants with 6 and $9 \mathrm{~g} / \mathrm{plant}$ of NPK had significant effect on plant height ,branching, stem thickness and weights of leaves and stems., On the other hand, spraying plants with the high level $(2.5 \mathrm{ml} / \mathrm{L})$ of Actosol gave the tallest plants ,the thickest stems, the highest values of No. of branches and weights. Moreover, the combined treatments of NPK at $6 \mathrm{~g} /$ plant with Actosol at $2.5 \mathrm{ml} / \mathrm{l}$, gave the tallest plants, the highest No. of branches, the thickest stems. were the most effective on increasing the vegetative growth parameters, this means the possibility of bio-fertilizers Actosol utilization in reducing the amount of NPK doses required for better growth of Zanthoxylum plants. 
Scientific Journal of Agricultural Sciences 3 (2): 13-29, 2021

Table 3. Effect of NPK and Actosol and their interactions on fresh and dry weight of leaves, stems and roots of Zanthoxylum piperitum plant during 2019and 2020seasons.

\begin{tabular}{|c|c|c|c|c|c|c|c|c|c|}
\hline \multicolumn{10}{|c|}{ Leaves fresh weight (g/plant) } \\
\hline \multicolumn{5}{|c|}{2019} & \multicolumn{5}{|c|}{2020} \\
\hline Treatments & *NPK1 & NPK2 & NPK3 & $\mathbf{M}(\mathbf{B})$ & Treatments & NPK1 & NPK2 & NPK3 & $\mathbf{M}(\mathbf{B})$ \\
\hline *Act 1 & 25.62 & 22.98 & 19.85 & 22.82 & Act 1 & 28.25 & 23.56 & 21.41 & 24.41 \\
\hline Act 2 & 28.75 & 35.99 & 39.52 & 34.75 & Act 2 & 30.11 & 38.06 & 43.85 & 37.34 \\
\hline Act 3 & 40.09 & 48.17 & 48.59 & 45.73 & Act 3 & 42.93 & 50.64 & 50.68 & 48.08 \\
\hline $\mathbf{M}(\mathbf{A})$ & 31.49 & 35.97 & 35.84 & & $\mathbf{M}(\mathbf{A})$ & 33.76 & 37.42 & 38.65 & \\
\hline \multirow[t]{6}{*}{ L.S.D 0.05} & A: 2.03 & B:1.83 & $\mathrm{AxB}: 3.17$ & & & A:2.01 & B :1.56 & AxB:2.07 & \\
\hline & \multicolumn{9}{|c|}{ Leaves dry weight (g/plant) } \\
\hline & 9.26 & 8.08 & 7.24 & 8.19 & & 10.55 & 8.59 & 7.94 & 9.03 \\
\hline & 9.82 & 12.31 & 13.80 & 11.98 & & 10.76 & 13.11 & 15.87 & 13.24 \\
\hline & 13.60 & 17.60 & 17.68 & 15.99 & & 13.94 & 18.29 & 18.37 & 16.87 \\
\hline & 10.89 & 12.70 & 12.58 & & & 11.75 & 13.33 & 14.06 & \\
\hline \multirow[t]{6}{*}{ L.S.D 0.05} & A: 1.0 & B:0.61 & AxB:1.06 & & & A: 0.94 & B: 0.87 & AxB: 1.51 & \\
\hline & \multicolumn{9}{|c|}{ Stems fresh weight $(\mathrm{g} /$ plant $)$} \\
\hline & 12.05 & 11.96 & 10.99 & 11.66 & & 12.78 & 12.41 & 11.87 & 12.35 \\
\hline & 12.65 & 17.34 & 20.78 & 16.92 & & 13.27 & 19.69 & 23.83 & 18.93 \\
\hline & 16.57 & 24.10 & 24.94 & 21.53 & & 17.55 & 25.16 & 25.47 & 22.72 \\
\hline & 13.76 & 17.80 & 18.57 & & & 12.78 & 19.08 & 20.39 & \\
\hline \multirow[t]{6}{*}{ L.S.D 0.05} & A: 1.34 & B: 1.13 & AxB: 1.96 & & & A: 0.82 & B: 0.78 & AxB: 1.36 & \\
\hline & \multicolumn{9}{|c|}{ Stems dry weight (g/Plant) } \\
\hline & 5.36 & 5.20 & 4.35 & 4.97 & & 5.77 & 5.43 & 4.97 & 5.39 \\
\hline & 5.54 & 8.02 & 9.23 & 7.59 & & 5.91 & 8.98 & 11.02 & 8.64 \\
\hline & 7.52 & 11.72 & 11.80 & 10.28 & & 8.50 & 12.33 & 12.68 & 11.17 \\
\hline & 6.14 & 8.31 & 8.39 & & & 6.73 & 8.92 & 9.56 & \\
\hline
\end{tabular}

L.S.D 0.05 A: 0.75 B:0.73

$14.01 \quad 13.11 \quad$ Roots fresh weight (g/plant)

$\begin{array}{cccccccr}14.01 & 13.11 & 12.85 & \mathbf{1 3 . 3 2} & 14.95 & 14.20 & 13.25 & \mathbf{1 4 . 1 3} \\ 15.10 & 18.35 & 19.78 & \mathbf{1 7 . 7 4} & 15.53 & 19.04 & 20.62 & \mathbf{1 8 . 4 0} \\ 19.54 & 23.14 & 24.38 & \mathbf{2 2 . 3 5} & 20.83 & 24.80 & 25.50 & \mathbf{2 3 . 7 1} \\ \mathbf{1 6 . 2 2} & \mathbf{1 8 . 2 0} & \mathbf{1 9 . 0 0} & & \mathbf{1 7 . 1 0} & \mathbf{1 9 . 3 5} & \mathbf{1 9 . 7 9} & \\ \text { A: } 1.49 & \text { B: } 0.69 & \text { AxB: } 1.19 & & \text { A: } 1.10 & \text { B: } 0.57 & \text { AxB: } 0.99 & \end{array}$

$\begin{array}{rrrr}\text { L.S.D 0.05 A: } 1.49 & \text { B: } 0.69 \quad \text { AxB: } 1.19 \\ \text { Roots dry weight (g/plant) }\end{array}$

$\begin{array}{cccccccc}9.54 & 8.94 & 8.77 & \mathbf{9 . 0 8} & 10.16 & 9.68 & 9.05 & \mathbf{9 . 6 3} \\ 10.47 & 12.63 & 13.58 & \mathbf{1 2 . 2 2} & 10.81 & 13.12 & 14.15 & \mathbf{1 2 . 6 9} \\ 13.83 & 16.23 & 17.11 & \mathbf{1 5 . 7 2} & 14.72 & 17.42 & 17.98 & \mathbf{1 6 . 7 0} \\ \mathbf{1 1 . 2 8} & \mathbf{1 2 . 6 0} & \mathbf{1 3 . 1 5} & & \mathbf{1 1 . 8 9} & \mathbf{1 3 . 4 1} & \mathbf{1 3 . 7 3} & \end{array}$

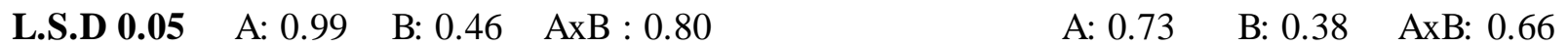

"NPK1: NPK 12g /plant, $\quad$ NPK2: NPK 9g/plant, $\quad$ NPK3: NPK 6g /plant, Act1 : Actosol 0ml/L, Act2 :Actosol $1.5 \mathrm{ml} / \mathrm{L}$ and Act3 $:$ Actosol $2.5 \mathrm{ml} / \mathrm{L}$. 


\section{Esmail S.E.A et al., 2021}

Many studies investigated the possibility of biofertilizers utilization instead of mineral fertilizers especially NPK, as previously reported by Ahmed (2017) on celery and dill, Shehata (2019) on parsley, Ahmed et al (2019) on chamomile Nofal et al., (2020 )on Erantheumum pulchellum plant and ElSayed et al., (2021) on Camelina sativa plant. The results clearly demonstrated the benefits of using solid HS as a management input to improve transplant quality in these crop species.

The pronounced effect of Actosol and other humic acid products on vegetative growth may be attributed to its effect on improving water retention, enhancing chelating of nutrients stimulating cells enlargement and elongation, leading to production of higher vegetative growth and greater proliferation of roots. The superiority of the plants that received Actosol at $2.5 \mathrm{ml} / 1$, in producing the heaviest total plant fresh and dry weights may be attributed (according to Masciandaro et al., 2002) to its role in enhancing the uptake of nutrients and oxygen, respiration, photosynthesis and cell elongation, due to the major functional groups of humic acid that has a positive effect on plant growth and the nutrient uptake ,specially nitrate (Cacco and Agnolla, 1984) and by stimulating enzyme activities ( Pouneva 2005) and Burkowska and Donderski 2007) .In this regard, El Sherif and Ismail (2017) on Curcuma longa, Sani and Jodaeian (2017) on Achillea millefolium and Saber et al., (2021) on Thymus kotschyanus, they found that humic acid significantly improved the growth development and yield and had a positive effect on root growth. Hanafy et al., (2017) on Artemisia abrotanum, found that application of Actosol at the rate of 1 and $2 \mathrm{ml} / \mathrm{pot}$, significantly increased the plant growth. El-Khateeb et al., (2017) reported increases in the fresh and dry weights of marjoram as a result of humic acid treatments. Mahmoud (2019) on artemisia found that the highest values for plant height were obtained from plants fertilized with actosol in both seasons

\subsection{Essential oil \% and yield/plant:}

The data in Fig.(1\&2) revealed that the essential oil (EO) $\%$ and yield/plant were affected signific antly with NPK in both seasons. Reducing NPK levels from $12 \mathrm{~g} / \mathrm{plant}(100 \%$,recommended ) to $9 \mathrm{~g} /$ plant $(75 \%)$ and $6 \mathrm{~g} /$ plant $(50 \%)$ increased signific antly essential oil\% and yield/plant and NPK at $12 \mathrm{~g} /$ plant gave the lowest oil\% (1.06\% and $1.03 \%)$ and oil yield/plant (0.115and $0.121 \mathrm{ml} /$ plant) in the first and second seasons, respectively. Reducing NPK rates from $100 \%$ up to $50 \%$ increased significantly essential oil $\%$ by $9.43 \%$ and $9.71 \%$ and essential oil yield/plant by 34.78 and $36.36 \%$ in the first and the second seasons, respectively. The reduction in essential oil productivity due to the effect of high levels NPK might be attributed to the production of more vegetative growth rather than the production of secondary products, i.e. essential oil. This result agreed with those reported by Puttanna et al., (2010) on Rosmarinus officinalis, Juárez et al., ( 2011) on Thymus vulgaris, El-Sayed et al (2015) on Ocimum sp, Hendawy et al., (2015) on Mentha piperita, Cáceres et al., (2017), Heikal and Helmy (2018), Hanafy et al., (2018) on Majorana hortensis and Hanafy et al., (2019) on Artemisia abrotanum.

The foliar application of Actosol had a positive and significant effect on essential oil productivity of Z.piperitum plant in both seasons. The control treatments had the lowest EO\%. The foliar application of Actosol at $1.5 \mathrm{ml} / \mathrm{l}$. gave the highest oil \% (1.16\% and $1.13 \%$ ), while Actosol at $2.5 \mathrm{ml} / \mathrm{l}$. gave the highest oil yield/plant $(0.18$ and $0.19 \mathrm{ml} / \mathrm{plant})$, in the first and second seasons, respectively. The high value of oil yield accompanying high concentration of actosol indicates its significant role in enhancing the uptake of nutrients and oxygen, respiration, photosynthesis (Cacco and Agnolla, 1984) and by stimulating enzyme activities (Pouneva 2005 and Burkowska and Donderski 2007), which in turn increased the oil yield. Similar results were reported by El-Sayed et al., (2016), Hanafy et al., (2018 and 2019).

The interaction between NPK and Actosol had a significant effect on essential oil\% and oil yield/plant. The highest essential oil\% (1.30\% and $1.27 \%)$ were recorded in plants fertilized with $6 \mathrm{~g}$ NPK and sprayed with $1.5 \mathrm{ml} / \mathrm{l}$, whereas oil yield/plant $(0.216$ and 0.220 ml)was the highest with $6 \mathrm{~g} / \mathrm{plant} \mathrm{NPK}+$ Actosol 2.5 ml/l. EL-Gohary et al., (2014)on Mentha piperita L found that essential oil content (\% or ml plant-1) and its major constituents increased with the foliar nutrition of humic acid. Also, Auimoviu et al., (2015) mentioned that the application of bio-humus (RoyalOfert) significantly increased it in anise plant. Barghamadi and Najafi (2015) on Ajowan (Carum copticum ) reported that humic acid increased essential oil\% and yield. 


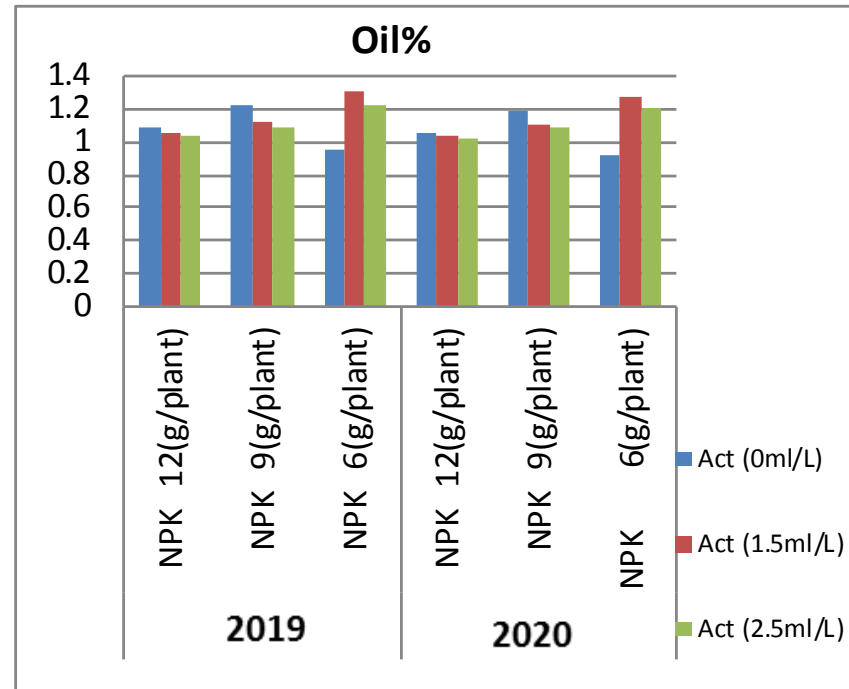

Fig.1

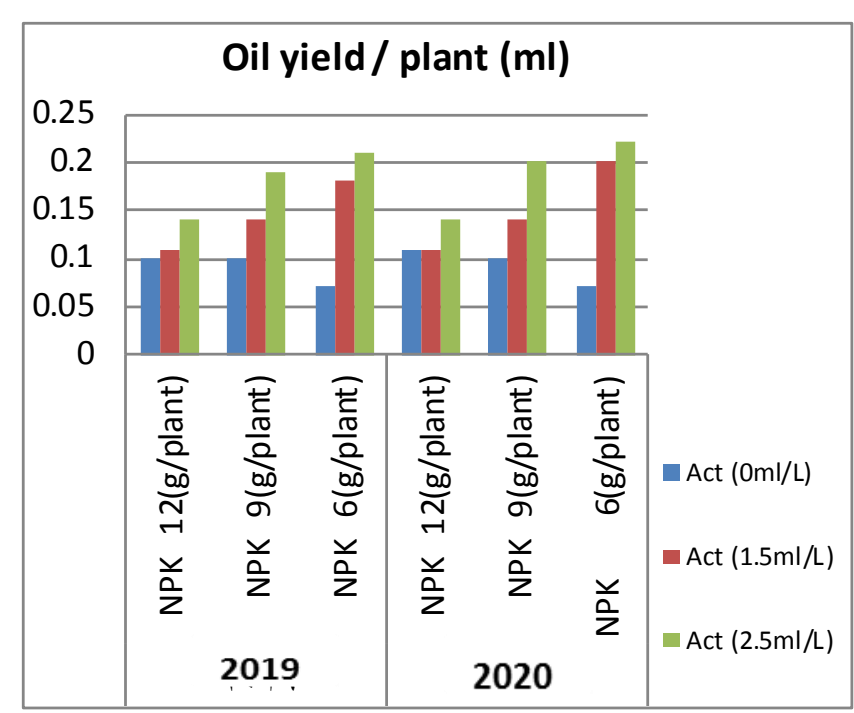

Fig.2

Fig.1\&2. Effect of NPK and Actosol and their interactions on essential oil \% and yield/plant of Zanthoxylum piperitum plant during 2019and 2020 seasons .

\subsection{Essential oil composition :}

It was performed by GC-MS analysis, the essential oil composition obtained from the leaves of $Z$.piperitum plants subjected to NPK+ Actosol treatments are shown in Table (4). About Twenty compounds were identified, representing : $\beta$ phellandrene, cyclohexanol ,germacrene-D , geranyl acetate, $\alpha$-pinene and 1,8-cineole, were found to be the dominant compounds. These results were in agreement with those reported by Jiang and Kubota (2004) and Chang and Kim (2008). In our study plants treated with T2 ( NPK 12g/plant+ Actosol 1.5 $\mathrm{ml} / \mathrm{L}$ ) , T5( NPK 9g/plant+ Actosol $1.5 \mathrm{ml} / \mathrm{L}$ and T8 (NPK 6g/plant+ Actosol $1.5 \mathrm{ml} / \mathrm{L}$ ) in the first season were the most effective treatment in increasing the percentages of $\beta$-phellandrene, cyclohexanol and germacrene-D, the total amount reached 21. 6, 13 . 7and $12.6 \%$, with T2, 21.6, 13.8 and $12.6 \%$ with T5 and $21.3,13.4$ and $12.3 \%$ with T8. whereas in the second season the highest percentages these components were $23.1 \%$ with $\mathrm{T} 8,13.3 \%$ with T7and $11.8 \%$ with T3,respectively. The percentage of geranyl acetate was the highest with $\mathrm{T} 9$ and $\mathrm{T} 5$, the percentage of $\alpha$-pinene reached the highest value with T9, whereas, the 1,8-cineole \% was the highest with $\mathrm{T} 9$ and $\mathrm{T} 3$, in the first and the second seasons, respectively. The nerolidol \% reached to the maximum values in both seasons, with the treatment T9. These results were in agreement with those reported by Jiang and Kubota (2004) and Chang and Kim (2008). In our observations, the percentages of some main components showed seasonal variation as affected with the same treatments. As reported by Jiang and
$\operatorname{Kubota}(2004)$ the essential oils of fruits and dried pericarp of Japanese pepper contained citronellal, linalool, and methyl cinnamate and geraniol. large amount of d-limonene, beta-phellandrene, and myrcene. Yang (2008) revealed that the essential oil of many species of Zanthoxylum contained linalyl acetate, linalool ,limonene, sabinene , alpha-terpineol, myrcene, 1,8-cineole. Whereas, Chang and Kim (2008) on Zanthoxylum pipperitum revealed that EO $\%$ from Korean and Chinese plant were 2.0 and $1.2 \%$ $(\mathrm{w} / \mathrm{w})$ respectively, and $\beta$-phellandrene, sabinene, terpinen-4-ol and linalool were the most abundant compound in the Korean and limonene, geranyl acetate, citronellal, and phellandral (each $>5 \%$ ), in Chinese plant . Moreover, Bisht and Chanotiya (2011) stated that the leaf essential oils of Z. armatum (GC-MS) contained high proportion of non-terpenic acyclic ketones(2-undecanone and 2-tridecanone) and low of undec-10-en-1-al and p-phellandren-8-ol,and signific ant amounts of oxygenated monoterpenes( 1,8 cineole, linalool, terpinen-4-ol, and alpha-terpineol) and sesquiterpene hydrocarbons (trans-caryophyllene, a-humulene and germacrene D). Kim (2012) analyzed essential oil in Z.piperitum by GC-MS in both leaves, he revealed that the amount of monoterpenes at different developmental stages were significant, the major compounds were $\beta$-phellandrene, citronella , $\beta$ myrcene, $\alpha$-pinene , trans-caryophyllene, and fanesyl acetate. Fujita et al., (2017) stated that volatile terpenes of Japanese pepper ( $Z$. piperitum) accumulated inside the secretory cavities of leaves, the sesquiterpenes $\beta$ caryophyllene and germacrene- $D$ and the monoterpene $\beta$-phellandrene were the major. 
Esmail S.E.A et al., 2021

Table 4. Effect of NPK and Actosol and their interactions on the essential oil constituents of Zanthoxylum piperitum plant during 2019 and 2020 seasons.

\begin{tabular}{|c|c|c|c|c|c|c|c|c|c|c|c|c|c|c|c|c|c|c|c|c|c|}
\hline 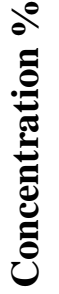 & 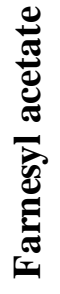 & 窇 & & 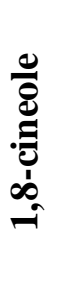 & 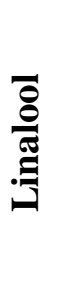 & 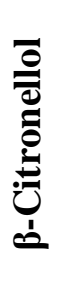 & 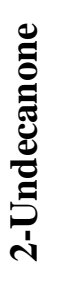 & 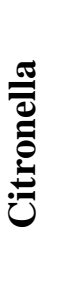 & 冚 & 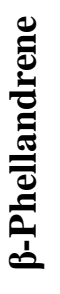 & $\sum_{\infty}^{\infty}$ & 串 & 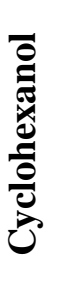 & 完 & 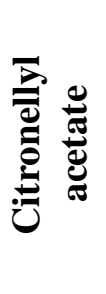 & 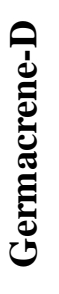 & 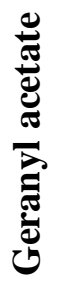 & 窇 & 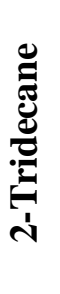 & 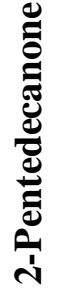 & 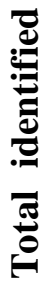 \\
\hline
\end{tabular}

\begin{tabular}{|c|c|c|c|c|c|c|c|c|c|c|c|c|c|c|c|c|c|c|c|c|c|}
\hline $\mathrm{T} 1^{*}$ & 1.1 & 5.5 & 1.7 & 2.9 & 1.4 & 1.5 & 1.3 & 1.5 & 0.8 & 19.2 & 1.8 & 1.9 & 11.6 & 2.3 & 1.4 & 9.6 & 2.1 & 1.4 & 3.0 & 2.1 & 74.1 \\
\hline $\mathrm{T} 2$ & 1.6 & 6.0 & 1.4 & 3.3 & 1.4 & 1.9 & 1.3 & 1.6 & 1.1 & 21.6 & 1.9 & 1.9 & 13.7 & 2.3 & 1.7 & 12.6 & 3.4 & 1.8 & 3.2 & 2.9 & 86.6 \\
\hline T3 & 0.7 & 5.6 & 0.6 & 3.7 & 0.5 & 1.0 & 0.5 & 0.7 & 0.2 & 20.7 & 1.1 & 1.0 & 12.8 & 1.4 & 0.8 & 11.7 & 2.3 & 0.9 & 2.7 & 2.0 & 70.9 \\
\hline $\mathrm{T} 4$ & 2.2 & 6.7 & 2.1 & 3.5 & 2.0 & 3.2 & 2.0 & 2.2 & 1.8 & 17.2 & 2.4 & 2.4 & 11.3 & 2.7 & 2.2 & 10.4 & 3.4 & 2.3 & 3.9 & 3.2 & 87.1 \\
\hline T5 & 1.5 & 6.1 & 1.4 & 3.6 & 1.3 & 2.0 & 1.4 & 1.3 & 1.2 & 21.6 & 2.1 & 1.8 & 13.8 & 2.1 & 1.8 & 12.6 & 3.7 & 1.8 & 3.3 & 3.02 & 87.4 \\
\hline T6 & 1.9 & 6.0 & 2.5 & 3.2 & 2.2 & 2.6 & 2.1 & 2.2 & 1.6 & 18.3 & 2.6 & 2.6 & 11.4 & 3.0 & 2.1 & 9.6 & 2.8 & 2.2 & 2.0 & 1.8 & 82.7 \\
\hline $\mathrm{T} 7$ & 0.9 & 5.7 & 0.8 & 3.0 & 0.8 & 1.3 & 0.7 & 0.9 & 0.4 & 20.9 & 1.3 & 1.3 & 13.0 & 1.7 & 1.0 & 11.9 & 2.6 & 1.2 & 2.9 & 2.2 & 74.5 \\
\hline T8 & 1.3 & 5.9 & 1.2 & 3.1 & 1.2 & 1.7 & 1.1 & 1.3 & 0.8 & 21.3 & 1.7 & 1.7 & 13.4 & 2.1 & 1.4 & 12.3 & 3.3 & 2.4 & 3.0 & 2.6 & 82.8 \\
\hline T9 & 2.6 & 7.6 & 2.6 & 4.0 & 2.5 & 5.0 & 2.5 & 2.6 & 2.4 & 13.8 & 2.8 & 2.8 & 9.4 & 3.1 & 2.7 & 8.8 & 3.5 & 2.8 & 6.8 & 2.3 & 90.6 \\
\hline & & \multicolumn{20}{|c|}{2020} \\
\hline T1 & 1.5 & 4.6 & 2.0 & 2.3 & 2.9 & 1.9 & 1.8 & 1.2 & 1.2 & 15.1 & 2.0 & 2.4 & 12.6 & 2.1 & 1.8 & 10.0 & 2.1 & 1.7 & 3.2 & 2.5 & 74.9 \\
\hline $\mathrm{T} 2$ & 1.5 & 4.8 & 1.9 & 2.4 & 2.7 & 1.9 & 2.0 & 2.0 & 2.1 & 20.3 & 1.3 & 2.3 & 11.3 & 2.5 & 2.9 & 10.7 & 2.2 & 2.5 & 2.5 & 3.2 & 83.0 \\
\hline T3 & 3.1 & 5.3 & 1.7 & 2.7 & 1.7 & 1.5 & 2.0 & 1.6 & 1.8 & 20.1 & 1.2 & 2.0 & 12.8 & 2.0 & 2.0 & 11.8 & 1.8 & 3.2 & 2.1 & 3.7 & 84.1 \\
\hline $\mathrm{T} 4$ & 3.4 & 4.1 & 2.2 & 2.1 & 2.9 & 2.2 & 2.3 & 2.3 & 2.4 & 16.8 & 1.8 & 2.6 & 9.7 & 2.7 & 3.0 & 9.0 & 2.4 & 2.7 & 3.6 & 3.5 & 81.7 \\
\hline T5 & 1.1 & 4.1 & 2.9 & 2.1 & 2.9 & 2.8 & 3.1 & 2.8 & 2.9 & 14.2 & 2.6 & 3.1 & 9.7 & 3.1 & 3.1 & 9.1 & 2.9 & 3.8 & 5.3 & 2.0 & 83.6 \\
\hline T6 & 1.9 & 4.9 & 1.7 & 2.4 & 4.2 & 3.2 & 2.0 & 1.6 & 1.8 & 18.3 & 1.3 & 2.0 & 11.8 & 2.0 & 2.0 & 10.8 & 1.8 & 3.0 & 2.3 & 2.9 & 81.9 \\
\hline T7 & 1.0 & 4.7 & 2.0 & 2.3 & 4.5 & 3.5 & 2.0 & 1.7 & 2.0 & 14.8 & 1.3 & 2.3 & 13.3 & 2.3 & 2.7 & 10.6 & 2.3 & 2.4 & 2.9 & 3.1 & 81.7 \\
\hline T8 & 1.3 & 5.2 & 1.1 & 2.6 & 2.1 & 1.2 & 1.3 & 1.3 & 1.4 & 23.1 & 0.5 & 1.6 & 12.3 & 1.8 & 2.3 & 11.3 & 1.5 & 1.8 & 1.3 & 3.6 & 78.6 \\
\hline T9 & 2.0 & 5.4 & 2.2 & 2.6 & 2.0 & 2.2 & 2.2 & 1.7 & 1.4 & 21.8 & 2.5 & 2.6 & 12.1 & 3.8 & 1.7 & 10.0 & 1.6 & 2.0 & 6.7 & 3.4 & 89.9 \\
\hline
\end{tabular}
Actosol $1.5 \mathrm{ml} / \mathrm{L}$, T6: NPK 9g/plant+ Actosol $2.5 \mathrm{ml} / \mathrm{L}$, T7: NPK 6g/plant, T8: NPK 6g/plant+ Actosol 1.5 m1/L and T9: NPK 6g/plant+ Actosol $2.5 \mathrm{ml} / \mathrm{L}$ 


\subsection{Chemical constituents:}

\subsubsection{Total chlorophylls and total carbohydrates :}

Data illustrated in Fig. (3) show that the application of NPK had a slight effect on the content of total chlorophylls of $Z$. piperitum, in both seasons. But,a positive effect had been realized as the combination between 6g/plant NPK and $2.5 \mathrm{ml} / \mathrm{L}$ Actosol resulting in the highest value (57.6 and 58.9 spad unit) in the two seasons, respectively. There was a marked increase in chlorophyll content with the increase in Actosol level. This result agreed with Hassan et al., (2015) on Ocimum basilicum L. who stated that biofertilizer at 4 and $6 \mathrm{~g} / \mathrm{l}$ (ADY),with NPK greatly chlorophyll content. El-Khateeb et al., (2017) on Majorana hortensis obtained the highest content with humic acid (2.5 ml/l). Ahmed (2017) on celery and dill plants, revealed that bio fertilizer + $50 \%$ NPK significantly increased total chlorophylls. Shehata (2019) on parsley recommended the treatment of $200 \mathrm{mg} / \mathrm{l} \mathrm{humic} \mathrm{acid}+50 \%$ of recommended NPK for growth and chlorophyll content.

The response of total carbohydrates content to the application of NPK and Actosol (Fig .4 ), revealed that, the carbohydrates content didn't differ markedly among the different NPK doses, but NPK 75\% (9g/ plant) showed a significant increase in the second season. Moreover, the plants treated with NPK at $9 g /$ plant gave a slight increase in carbohydrates content. Masciandaro et al., (2002) attributed this effect to its role in enhancing the uptake of nutrients, oxygen uptake, respiration and photosynthesis. Khalid and Shedeed (2015) reported that NPK at the high level had a positive total carbohydrate in Nigella sativa plant. Also, Abdelaziz et al., (2007) indicated that biofertilizers could replace conventional NPK fertilizers in rosemary cultivation with a signific ant increase in carbohydrate content. Ghatas (2020) indicated that NPK and bio-fertilization significantly increased the chemical constituents. Abou- El Salehein etal (2021) found that application of NPK fertilization reflected a significant difference on chemical contents of herb plants total carbohydrates and pigments (chlorophyll a, b, a+ b, and carotenoids) of Ocimum basilicum $\mathrm{L}$ ,.El-Sayed et al., (2021) on Camelina sativa reported that the contents of chlorophyll and total carbohydrates increased by the use of $75 \% \mathrm{NPK}+$ Bio.fertilizer.

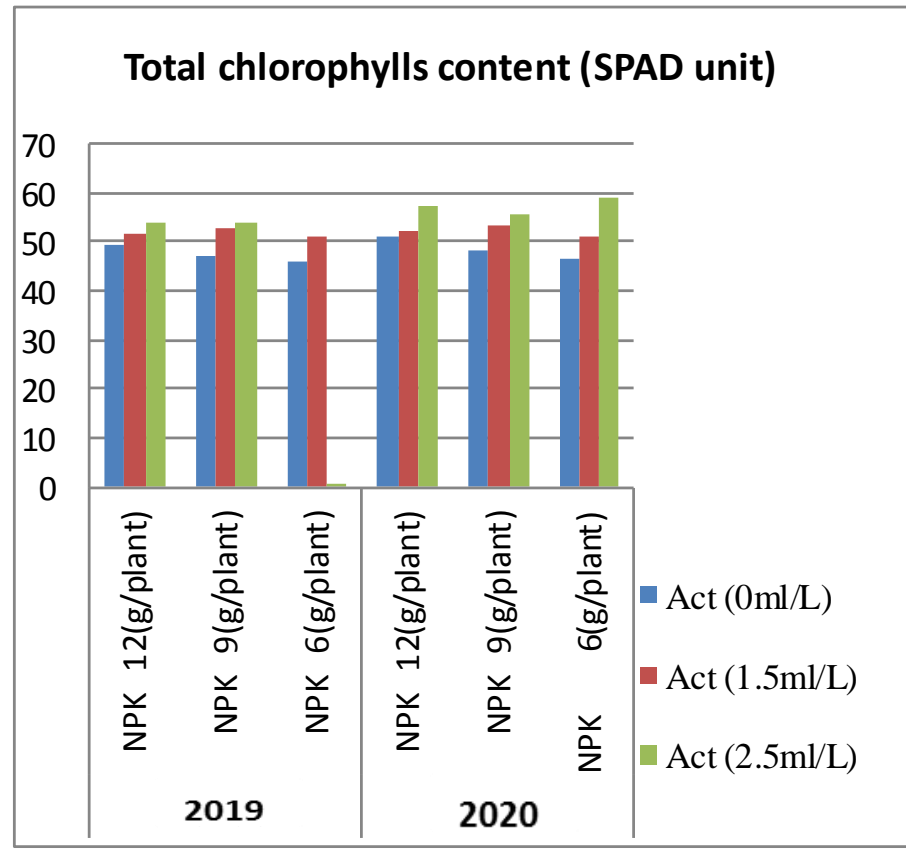

Fig.3
Total carbohydrates \% D.W

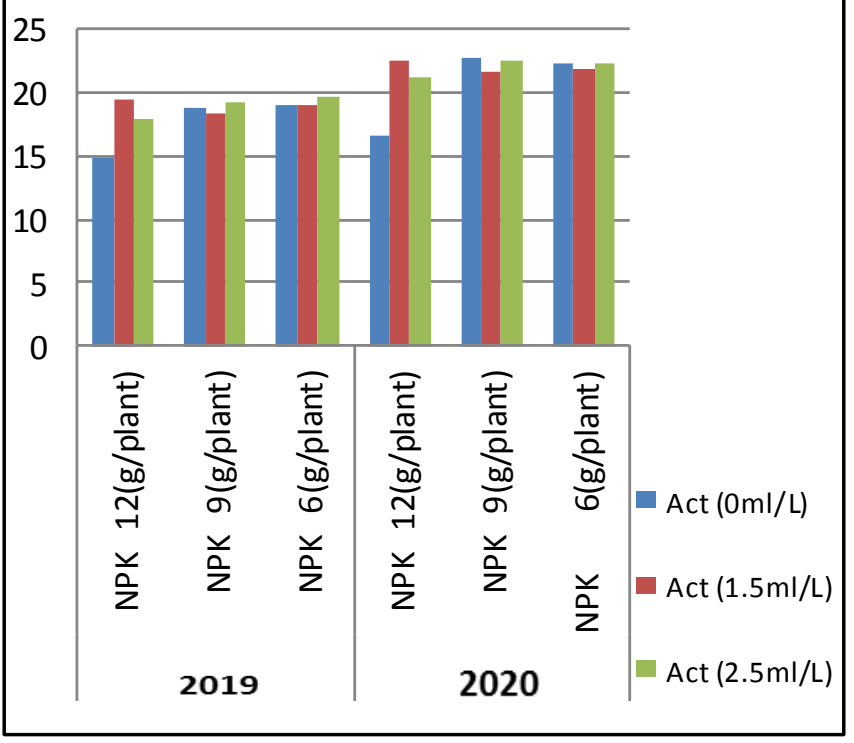

Fig.4

Fig3\&4. The response of total chlorophylls (spad uint) and total carbohydrates(\%DW) in leaves of $Z$. piperitum plant to NPK and Actosol treatments during 2019 and 2020 seasons. 


\subsubsection{Total phenolic and flavonoid contents:}

The total phenolic contents in $Z$. piperitum leaves of the treated plants Fig. ( 5 ) were measured according to the Folin-Ciocalteu method. The determined values, in the first season, ranged from $4.45 \mathrm{mg}$ GAEg-1 DW in plants treated with NPK12 $\mathrm{g} /$ plant +Actosol $1.5 \mathrm{ml} / 1$ to $7.94 \mathrm{mg} \mathrm{GAE} \mathrm{g-1} \mathrm{DW}$ with the treatment of NPK 9 g/plant +Actosol $1.5 \mathrm{ml} / 1$, whereas in the second season, it ranges between 4.70 and 8.45 for the plants treated with NPK12 g/plant +Actosol 1.5ml/1 and NPK6 g/plant + Actosol $1.5 \mathrm{ml} / 1$, respectively. In both seasons, decreasing the dose of NPK from 12g/plant to 9 or 6 $\mathrm{g} /$ plant markedly increased the total phenolic contents in leaves. The same trend was also recorded with the increase in Actosol concentration. This indicating that plants treated with NPK 9g/plant + Actosol at 1.5 or $0 \mathrm{ml} / \mathrm{L}$ or NPK at $6 \mathrm{~g} /$ plant +1.5 $\mathrm{ml} / \mathrm{L}$ Actosol was highly recommended for increasing the contents of phenolic compounds .
The obtained data Fig. (6 ) regarding the response of total flavonoid content to the application of NPK and Actosol, showed that the values ranged from 1.75 to $4.74 \mathrm{mg} / \mathrm{g}$ dry weight (Quercetin equivalents), in the first season and from 1.91 to 4.41 $\mathrm{mg} / \mathrm{g}$ dry weight (Quercetin equivalents), in the second season. The highest value in the first season $(4.74 \mathrm{mg})$ was determined in the plants treated with NPK 9gm/plant + Actosol $1.5 \mathrm{ml} / \mathrm{L}$, followed by the treatment of NPK 6g/plant + Actosol $1.5 \mathrm{ml} / \mathrm{L}$. The highest value in the second one (4.41) was determined in the plants treated with NPK 9g/plant, followed by the treatment of NPK6 g/plant + Actosol $1.5 \mathrm{ml} / \mathrm{L}$. It is worthy to mention that the treating plants with $\mathrm{NPK}(6 \mathrm{~g} / \mathrm{plant})+\operatorname{Actos} \mathrm{l}(1.5 \mathrm{ml} / \mathrm{L})$ seemed to increase the medicinal activity and the contents of phenolic and flavonoid contents in this plant. In addition, represent a rich source of naturally occurring flavonoids

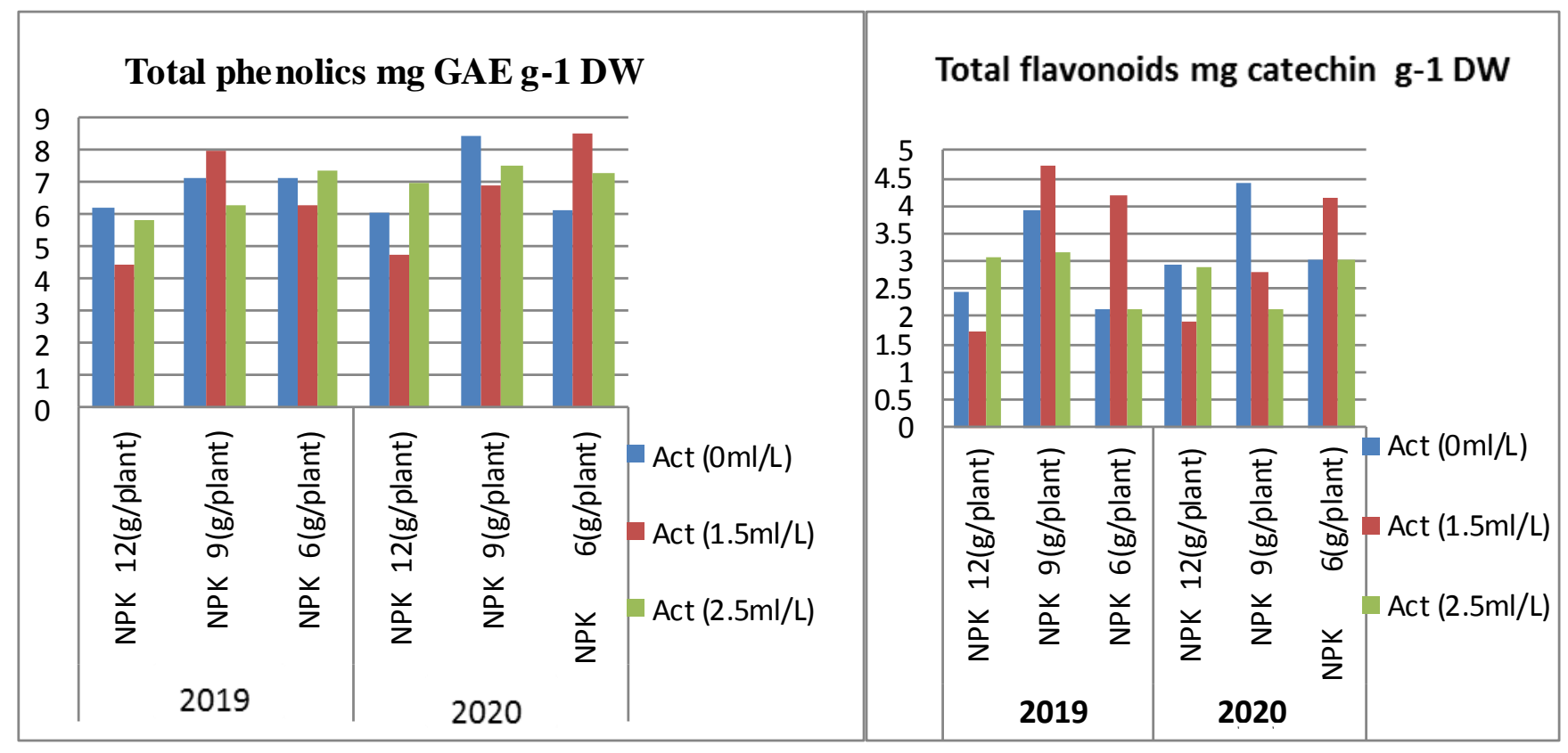

Fig.5

Fig.6

Fig.5\&6. Effect of NPK and Actosol and their interactions on contents of total phenolic and total flavonoid in leaves of $Z$. piperitum plant during two seasons 2019and 2020.

\subsubsection{Antioxidant activity:}

In both seasons, the methanolic extracts of $Z$. piperitum leaves from the different treatments were prepared to evaluate their antioxidant activity by DPPH method. The IC50 values (a midpoint of 50\% between zero and full inhibition of diazo dye formation) of superoxide (O2-)-scavenging activity.
The determined values, in the first season, ranged from 3.04 to 13.40 , and from 3.85 to $13.45(\mu \mathrm{g} / \mathrm{ml}$ methanol Extract) in the second one. Data in Fig. (7) revealed a great variation in antioxidants scavenging activities against DPPH assay. The crude extract was able to scavenge $50 \%$ of both DPPH radicals ranging from 3.04 to 13.40 in the first season, as the plants 
received $12 \mathrm{~g} /$ plant $\mathrm{N}$ PK showed the highest IC50, while that treated with $6 \mathrm{~g} /$ plant NPK + Actosol 1.5 $\mathrm{ml} / \mathrm{L}$ exerted the lowest IC50values (3.04), this was the case in the first season. The crude extract in the second season, was able to scavenge $50 \%$ of both DPPH radicals ranging from 3.85 to $13.45(\mu \mathrm{g} / \mathrm{ml}$ methanol Extract), as the plants received $12 \mathrm{gm} /$ plant NPK showed the highest IC50, while that treated with $6 \mathrm{gm} /$ plant NPK + Actosol $1.5 \mathrm{ml} / \mathrm{L}$ exerted the low est IC50value (3.85).
In this regared, Pandey et al., (2015) found that organic amendments in combination with chemical fertilizer significantly improved the antioxidant capacity of the marigold leaf extracts(DPPH activity) than the control. Also, Sheikh and Ishak ( 2016) showing that nitrogen application improves antioxidant activity. Bistgani, et al., (2018) reported that the application of combined fertilizers (NPK $+\mathrm{CM}+\mathrm{VC}$ ) significantly increased the biomass and improved the antioxidant properties.

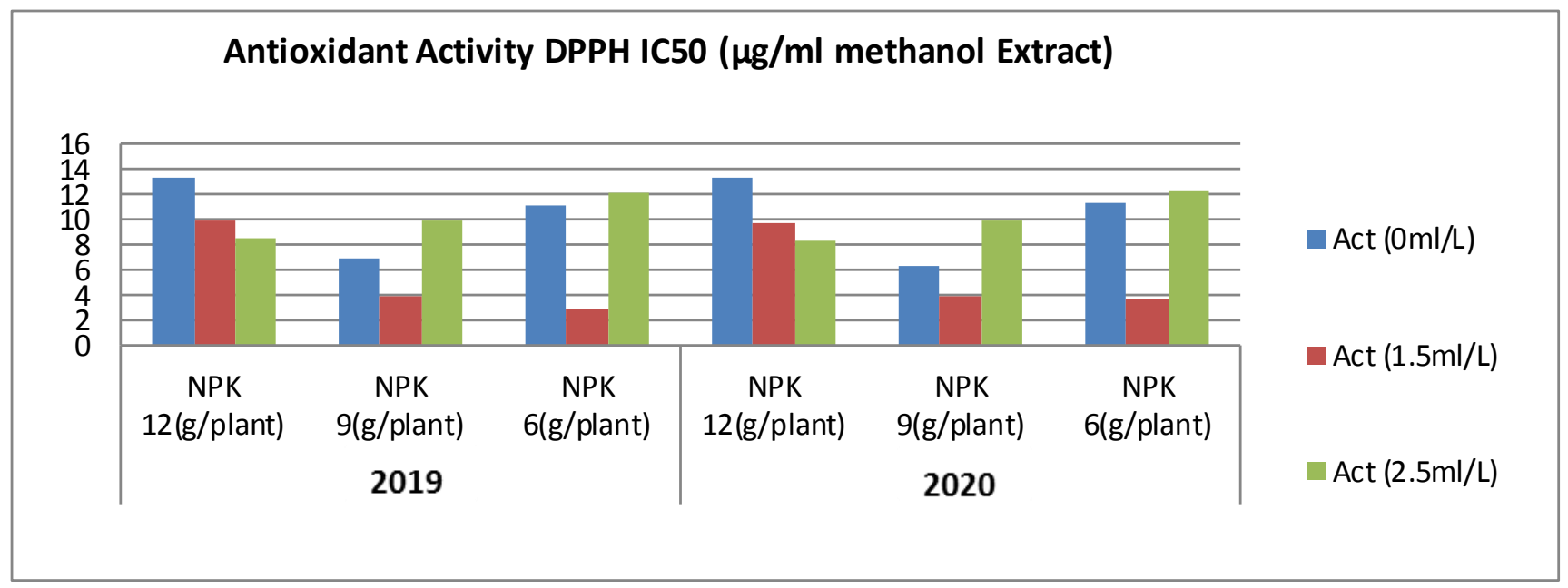

Fig.7

GAE

DPPH $\mathrm{IC}_{50}$

Fig.7. Effect of NPK and Actosol and their interactions on the antioxidant activity in the methanolic

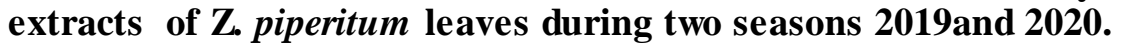

\subsection{4. $N$, $P$ and $K$ contents:}

The contents of N,P and $\mathrm{K}$ in leaves slightly differed between the different NPK dose in two growth seasons. Fig (8). The N-content (\%) in the leaves of plants treated with the low dose of NPK and sprayed with Actosol at $1.5 \mathrm{ml} / 1$. was the highest, in both seasons.( 3.05 and $3.07 \%$ D.W), which followed by the treatment of NPK at $9 \mathrm{~g} /$ plant without Actosol, in the first season, and the treatment of NPK at $12 \mathrm{~g} / \mathrm{plant}+$ Actosol at $2.5 \mathrm{ml} / 1$, in the second one. Also, the plants treated with $6 \mathrm{~g} /$ plant NPK $+2.5 \mathrm{ml} / \mathrm{L}$ Actosol contained higher $\mathrm{P} \%$ in the first season as compared with the second one, giving 0.14 and $0.3 \%$ D.W. However, there was a pronounced reduction in potassium content in plants treated with $9 \mathrm{~g} /$ plant NPK $+1.5 \mathrm{ml} / 1$ Actosol. . Enhancement in the antioxidant activity may be due to an overall promoting effect of organic and NPK regimes on plant metabolic activities, as humic substances improves water retention, enhances chelating of plant nutrients and stimulates root mass and plant growth (Masciandaro et al., 2002). In addition, Pouneva (2005) and Burkowska and Donderski (2007) confirmed the role of humic substances in enhancing the uptake of nutrients and photosynthesis that has a positive effect on plant grow th. Abdelaziz et al., (2007) indicated that biofertilizers could replace conventional NPK fertilizers in rosemary cultivation with a significant increase in growth, total $\mathrm{N}, \mathrm{P}$, carbohydrate content. Samy, et al., (2015) stated that the foliar application of 0.5 and $1 \mathrm{~g} / \mathrm{l}$ humic acid significantly affected the chemical composition (N, P, K, Total carbohydrates and inulin contents) of Jerusalem artichoke . than control treatment. On Thymus kotschyanus, Saber et al., (2021) stated that humic acid had a positive effect increasing nutrient uptake due to its effect on root growth. 
Esmail S.E.A et al., 2021

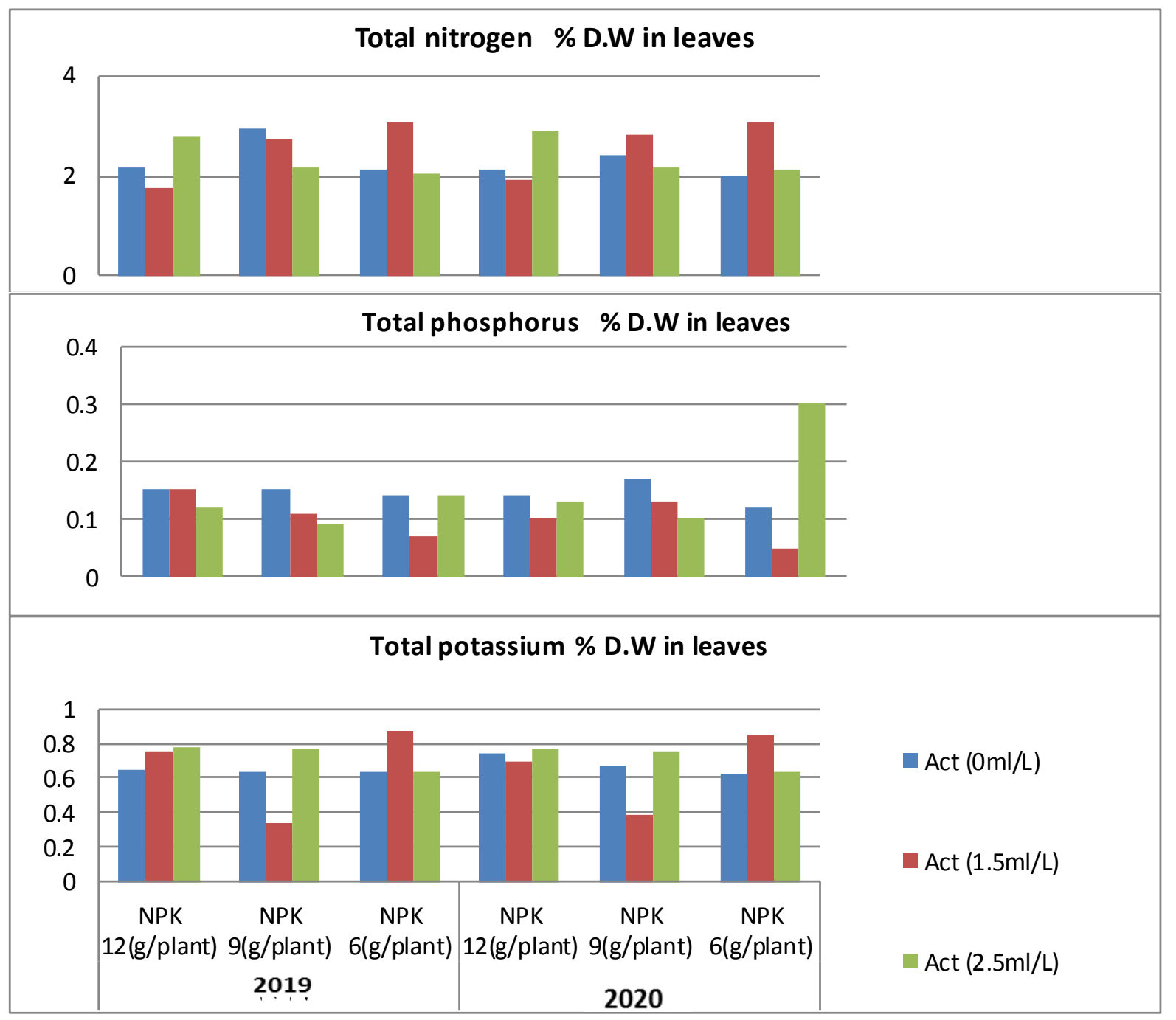

Fig.8. Effect of NPK and Actosol and their interactions on contents of N,P and K (\% DW) in leaves of $Z$. piperitum plant during two seasons 2019and 2020.

\section{CONCLUSION}

We could conclude that, Zanthoxylum piperitum treated with NPK at 6 and $9 \mathrm{~g} / \mathrm{plant}+$ Actosol 2.5 $\mathrm{ml} / \mathrm{L}$ in both seasons affected significantly on improving the plant growth, contents of phytochemicals and essential oil production. Also we cannot exclude that other treatments were found to improve plant behavior, but it was only in one direction. Actosol at $1.5 \mathrm{ml} / \mathrm{l}$ gave the highest oil $\%$,while $2.5 \mathrm{ml} / 1$ gave the highest oil yield/plant. Howevre, Zanthoxylum piperitum plants shows great ability to grow under the Egyptian conditions which will open series of under studies on their bioactive derived compounds in the pharmaceutical industries.

\section{REFERENCES}

Abdelaziz ME, Hanafy AH, Shaaban MM, Pokluda R (2007). Fresh weight and yield of lettuce as affected by organic manure and biofertilizers. Conference of organic farming, Czech Univ. Agric.,Czech Republic, 212-214.

Abou- El Salehein ME, Ibrahim DM, Helal A (2021) . A.Effect of NPK, Humic acid and dry yeast on growth, oil yield and chemical constituents of sweet basil (Ocimum basilicum L.). Journal of Productivity and Development 26(3):513-529 .

Adams RP (1995). Identification of essential oil components by gas chromatography mass spectroscopy. Allured, Carol, Stream, Illions, USA,PP.1-2.Identification of Essential Oil Components by Gas Chromatography-Mass Spectroscopy, Allured Publ. Corp., Carol Stream, Illinois.

Ahmed MI, Mahd TMM , Mansour AM, Alzahar H, Sadek WMA (2019). Effect of chamomile flower addition to diets of lactating zaraibi goats on its 
productive performance. Nutrition and Feeds , 22 (3): $479-489$

Ahmed ZA (2017). Effect of NPK and bio fertilization on growth and oil yield of celery (Apium graveolens L.) and dill (Anethum graveolens L.) Plants. J. Plant Production, Mansoura Univ., 8 (2): $247-251$.

AOAC (1990). Official Methods of Analysis, $15^{\text {th }}$ eds., Published by Association of Official Analytical Chemists, Washington, D.C., U. S. A. 684 p.

Auimoviü MG, Dolijanoviu ZK, Oljapa SI, Kovapeviü DC, OljaPa MV ( 2015). Effect of organic and mineral fertilizers on essential oil content in Caraway, Anise and Corriander fruits Acta Sci. Pol., Hortorum Cultus 14(1) 95-103.

Azzaz NA, Hassan EA, Hamad EH (2009). The chemical constituent and vegetative and yielding characteristics of Fennel plants treated with organic and bio-fertilizer instead of mineral fertilizer. Australian Journal of Basic and Applied Sciences, 3: 579-587.

Badran FS, Safwat MS (2004). Response of fennel plants to organic manure and biofertilizers in replacement of chemical fertilization. Egyptian Journal of Agriculture Research, 82: 247-256.

Barghamadi K, Najafi SH (2015). Effect of different levels of nitroxin and humic acid on quantitative properties and essential oil of Ajowan (Carum copticum (L.) C. B. Clarke). Journal Of Horticultural Science, 29(3), 321-341.

Bisht D, Chanotiya CS ( 2011). 2-undecanone rich leaf essential oil from Zanthoxylum armatum. Nat Prod Commun, 6(1): 111-4.

Bistgania ZE, Siadata SA, Bakhshandeha A, Pirbaloutib AG, Hashemic M, Maggid F, Morshedlo MR (2018). Application of combined fertilizers improves biomass, essential oil yield, aroma profile, and antioxidant properties of Thymus daenensis Celak. Industrial Crops and Products.121 :434-44.

British Pharmacopoeia (1963). Determination of Volatile Oils in Drugs. The Pharmaceutical Press, 17 Bloomsbury Square, W.C.I. London, p 213.

Burk owska A, Donderski W (2007). Impact of humic substances on bacterioplankton in eutrophic lake. journal of Ecology 55 (1), 155-160.

Cacco G and DellAgnolla G (1984). Plant growth regulator activity of soluble humic substances. Can. J. Soil Sci. 64, 25-28.

Caceres JA, Cuervo JL, Rodriguez JL (2017). Effect of organic fertilization on yield and quality of rosemary (Rosmarinus officinalis L.) essential oil. Agronomía Colombiana, 35(2):232-237.
Chang KM and Kim GH (2008). Comparative analysis of volatile flavor compounds from Zanthoxylum piperitum A.P. DC. Journal of Food Science Nutrition 13: 33-39.

Chang CC, Yang MH, Wen HM, Chern JC (2002). Estimation of total flavonoid content in propolis by two complementary colorimetric methods. Journal of Food and Drug Analysis 10: 178-182.

Chen Y, Avaid T (1990). Effect of humic substances on plant growth MacCarthy, C.E. Clapp, R.L. Malcolm, and P.R. Bloom (eds.), Humic Substances in soil and Crop Sciences: Selected Readings. Soil Science Society of America, Madison, Wisconsin. pp. 161-186

Choi HJ, Song JH, Kwon DH, Baek SH, Ahn YJ (2008). Antiviral activity of Zanthoxylum species against influenza virus. Korean J. Med. Crop. Sci. 16: 273-278.

Cottenie A, Verloo M, Kiekens L, Velghe G, Camerlynck R (1982). Chemical Analysis of Plant and Soil. Laboratory of Analytical and Agrochemistry, State Univ. Ghent. Belgium. PP. 100 - 129.

Dubois M, Gilles K, Hamilton J, Rebers P, Smith F (1956). Colorimetric method for determination of sugars and related substances. Analytical Chemistry, 28(3): 350-356.

EL- Gohary AE, El-Sherbeny SE, Ghazal GMEM, Khalid KA, Hussein MS (2014). Evaluation of essential oil and monoterpenes of peppermint (Mentha piperita L.) under humic acid with foliar nutrition. J. Mater. Environ. Sci. 5 (6):1885-1890.

El Sherif, F, Ismail EG (2017). Effects of plant spacing and its association with Humic acid application on the growth, yield and active composition in Curcuma longa. American Journal of Plant Biology 2(4): 106-113.

El-Khateeb MA, El-Attar AB, Nour RM.(2017). Application of plant biostimulants to improve the biological responses and essential oil production of marjoram (Majorana hortensis, Moench) plants. Middle East Journal of Agricultural. Research 6(4): 928-941.

El-Sayed AA, El-Hanafy SH, El-Ziat RA (2015). Effect of chicken manure and humic acid on herb and essential oil production of Ocimum sp. AmericanEurasian Journal of Agricultural and Environmental Sciences, 15 (3): 367-379.

El-Sayed AA, El-Liethy AS, Hendawy SF, Hefni OG (2021). Response of Camelina sativa oil to different levels of N-P-K and compost fertilizers. Journal of Ecological, 22(7):260-270. 
Freed RSP, Einensmith S, Gutez S, Reicosky D, Smail VW, Wolberg P(1989). MSTAT-C analysis of agronomic research experiments. Michigan Univ. East Lansing, USA.

Fujita Y, Koeduka T, Aida M, iSuzuki H Iijima Y, Matsui K (2017). Biosynthesis of volatile terpenes that accumulate in the secretory cavities of young leaves of Japanese pepper (Zanthoxylum piperitum): Isolation and functional characterization of monoterpene and sesquiterpene synthase genes .Plant Biotechnol (Tokyo). 34(1): 17-28.

Ghatas Y (2020). Impacts of Using some Fertilization Treatments in Presence of Salicylic Acid Foliar Spray on Growth and Productivity of Coriandrum sativum L. Plant. Journal of Plant Production 11(2):119-125.

Gomez KA, Gomez AA (1984). Statistical Procedures for Agricultural Research. $2^{\text {nd }}$ ed. John Wily and Sons. Inc. New York, USA., 97-107. PP. Hanafy MS, Ashour HA, Sedek FM (2018). Effect of some bio-stimulants and micronutrients on growth, yield and essential oil production of Majorana hortensis plants. International Journal of Environment, 7(1):37-52.

Hanafy MS, Heikal AAM, El-Ghawwas EO, Ali ZH (2019). The response of essential oil yield and chemical composition of Artemisia abrotanum L. plants to cattle manure and some biostimulants treatments. Middle East Journal of Applied Sciences 9(1):1-16.

Hanafy MS, Heikal AAM, El-Ghawwas EO, Ali ZH (2017). The effect of cattle manure and biostimulants on growth and essential oil production of southernwood Artemisia (Artemisia abrotanum L.) plant. Middle East Journal of Agricultural Sciences 6 (4): 1218-1231.

Hasan MDM, Dasilva JAT, LI X ( 2016). Regulation of phosphorus uptake and utilization: transitioning from current knowledge to practical strategies. Cellular and Molecular Biology Letters 21 (7).

Hashimoto K, Satoh $\mathrm{K}$, Kase T, Ishige A, Kubo M, Sasaki H, Nishikawa S, Kurosawa S, Yakabi K, Nakamura T (2001). Modulatory Effect of Aliphatic Acid Amides from Zanthoxylum piperitum on Isolated Gastrointestinal Tract. Planta Med 67: 179-181.

Hassan MR, El-Naggar AHM, Shaban EH, Mohamed MEA (2015). Effect of NPK and biofertilizers rates on the vegetative growth and oil yield of Ocimum basillicum L. plants Alexandria Science exchange journal $36: 58-72$.
He J, Jin Y, Turner NC, Chen Z, Liu H Y, Wang XL, Siddique KH, Li FM (2019). Phosphorus application increases root growth, improves daily water use during the reproductive stage, and increases grain yield in soybean subjected to water shortage. Journal of Environmental and Experimental Botany 166, 103816.

Heikal AAM, Helmy SS (2018). Effect of nitrogen fertilization and ascorbic acid on growth, essential oil and chemical composition of rosemary plant. Zagazig Journal of Agricultural Sciences, 45(1):87-103.

Hendawy FS, Hussein MS, El-Gohary AE, Ibrahim MA (2015). Effect of foliar organic fertilization on the growth, yield and oil content of Mentha piperita var. citrata. Asian Journal of Agricultural Sciences 9: 237-248.

Hosseini MS (2012). Macroelements nutrition (NPK) of medicinal plants. Journal of Medicinal Plants Research Vol. 6(12): 2249-2255.

Imaizumi Y, Ohi Y, Yamamura H, Ohya S, Muraki K, Watanabe $\mathrm{M}$ (1999). $\mathrm{Ca}^{2+}$ sparks as a regulator of ion channels activity Japanese Journal of Pharmacology. 80:1-8.

Issac RA, Kerber JD (1971). Atomic absorption and flame photometry: techniques and Uses in soil, plant and water analysis. In instrumental methods for analysis of soil and plant tissue. Soil Sci. Soc. Amer., Madison, WI, USA, pp 17-37.

Jackson ML (1973). Soil Chemical Analysis. Printice-Hall of India. Privat Limited, New Delhi. Text book. pp. 144-197.

Jiang L, Kubota K (2004). Differences in the volatile components and their odor characteristics of green and ripe fruits and dried pericarp of Japanese pepper (Zanthoxylum piperitum DC.). Journal of Agricultural Food Chem 52: 4197-4203.

Jin J, Wang G, Liu X, Pan X, Herbert SJ (2005). Phosphorus application affects the soybean root response to water deficitat the initial flowering and full pod stages. Soil Sci. Plant Nutr. 51 (7): 953-960. Juárez CR, Lyle E, Craker LE, Mendoza NM, Castillo JC (2011). Humic substances and moisture content in the production of biomass and bioactive constituents of Thymus vulgaris L. Rev. Fitotec. Mex.. 34 (3):183-188.

Kamsuk K, Choochote W, Chaithong U, Jitpak di A, Tippawangkosol P, Rivong D, Pitasawat B (2007). Effectiveness of Zanthoxylum piperitum-derived essential oil as an alternative repellent under laboratory and field applications. Parasitol Res 100: 339-345.

Kedare SB, Singh $R$ (2011). Genesis and development of DPPH method of antioxidant assay. 
Journal of food science and technology. 48(4): 412422.

Khalid KA, Shedeed MR (2015). Effect of NPK and foliar nutrition on growth, yield and chemical constituents in Nigella sativa L. Journal of Agricultural Mater. Environ. Sci., 6: 1709-1714.

Kim DO, Jeong SW, Lee CY (2003) . Antioxidant capacity of phenolic phytochemicals from various cultivars of plums .Food Chemistry81(3): 321-32.

Kim JH (2012). Seasonal variations in the content and composition of essential oil from Zanthoxylum piperitum. Journal of Ecology and Environment 35(3).

Lee S J , Lim KT (2008). Glycoprotein of Zanthoxylum piperitum $\mathrm{DC}$ has a hepatoprotective effect via anti-oxidative character in vivo and in vitro. 22:376385 .

Mahmoud ZHA (2019). Effect of cattle manure and some biostimulants on growth, yield, essential oil production and chemical composition on artemisia (Artemisia abrotanum L.) Plant .Ph. D. Thesis, Hort. Dept., Fac. Agric., Cairo Univ. 180 pp.

Marschner H (2012). Mineral Nutrition of Higher Plants. 3rd Edition. London: Academic, 315-330.pp.

Masciandaro G, Ceccanti B, Ronchi V, Benedicto S, Howard L (2002). Humic substances to reduce salt effect on plant germination and growth. Commun. Soil Sci. Plant Anal. 33; 365-378. Meda A, Lamien CE, Romito M, Millogo J, Nacoulma OG (2005). Determination of the total phenolic, flavonoid and praline contents in Burkina Fasan honey, as well as their radical scavenging activity. Food Chem., 91: 571-577.

Mohamed SA, El-Ganaini SS (2003). Effect of organic, mineral and bio-fertilizers on growth, yield and chemic al constituents as well as anatomy of broad bean (Vicia faba L.) plants growth in reclaimed soil. Egypt. J. Appl. Sci; 18(12): 38- 63.

Negi JS, Bisht VK, Bhandari AK, Singh P, Sundriyal RC (2011). Chemical constituents and biological activities of the genus Zanthoxylum: A review. African Journal of Pure and Applied Chemistry 5(12) : 412-416.

Netto AT, Campostrini EJ, Oliveira G, Bressan SRE (2005). Photosynthetic pigments, nitrogen, chlorophyll a fluorescence and SPAD 502 reading in coffee leaves. Scientia Hort., 104 (2): 199-209.

Nofal EMS, Menesi FA, El-Bably SZ, Abd Elrahman M (2020). Effect of NPK and humic acid on growth, flowering and chemical composition of (blue sake) Erantheumum pulchellum Andrews plant . Applied Ecology and Environmental Research 18 (2):2555-2567.
Okagu IU, Ndefo JC, Aham EC, Udenigwe CC (2021). Zanthoxylum Species: Acomprehensive review of traditional uses, phytochemistry, pharmacological and nutraceutical applications. Molecules, 26: 4023.

Pandey V, Patel A, Patra DD (2015). Amelioration of mineral nutrition, productivity, antioxidant activity and aroma profile in marigold (Tagetes minuta L.) with organic and chemical fertilization. Industrial Crops and Products. 76:378385.

Pouneva I (2005). Effect of humic substances on the growth of microalgal cultures. Russ J Plant Phys1 52:410-413.

Puttanna K, Prakasa EVS, Singh R, Ramesh S (2010). Influence of nitrogen and potassium fertilization on yield and quality of rosemary in relation to harvest number. Communications in Soil Science and Plant Analysis 41:190-198.

Ravindran PN (2017). The Encyclopedia of Herbs and Spices. CAB International Pp. 473-476

Saber M, Changizi M, Khaghani S, Gamariy an M, Pourmeidani A (2021) . Effect of drought and humic acid on morphological traits and essential oil content of Thymus kotschyanus .Plant Archives , 21(1): 2261- 2268.

Samavatipour P, Abdossi V, Salehi R, Samavat S, Moghadam AL (2019). Investigation of morphological, phytochemical, and enzymatic characteristics of Anethum graveolens L. using selenium in combination with humic acid and fulvic acid. Journal of Applied Biology \& Biotechnology, 7(6): 69-74.

Samy MM, Mohamed NA, Abd El-Aziz MG (2015). Effect of boron, copper and humic acid treatments on vegetative growth, yield and storability of Jerusalem artichoke Journal of Productivity and Development 20(3)(3):325-34.

Sani B, Jodaeian V (2017). Evaluation of humic acid effect on essential oil yield in yarrow medicinal plant by view of approaches in sustainable Agriculture. Journal of Agroecology and Natural Resource Management p-ISSN: 2394-0786, eISSN: 2394-0794, 4( 5 ).

Sharpley AN, Danie TC, Sims JT, Pote DH (1996). Determining environmentally sound soil phosphorus levels. J. Soil Water Conserv. 51, 160-166.

Shehata MN ( 2019). Parsley productivity and essential oil content as affected by chemical ,biofertilization and humic acid. Fayoum Journal of Agric. Res. and Dev., 33 (1).

Sheikh S, Ishak CF (2016) . Effect of nitrogen fertilization on antioxidant activity of Mas 
Esmail S.E.A et al., 2021

cotek(Ficus deltoidea Jack). Journal of Medicinal Plants Studies., 4(4): 208214 .

University, Qaemshahr, Iran International Journal of

Swaefy H, Weaam MF, Sakr RA, Sabh AZ, Ragab AA ( 2007). Effect of some chemical and biofertilizers on peppermint plants grown in sandy soil. 2.Effect on essential oil production, chemical composition and anatomical features. Annals Agric. Sci., Ain Shams Univ., Cairo, 52(2): 465-484.

Valiki S, Ghanbari SRH (2015). Comparative examination of the effect of manure and chemical fertilizers on yield and yield components of rosemary (Rosemarinus officinalis L.) .Department of Agronomy, Qaemshahr Branch, Islamic Azad

Agronomy and Agricultural Research 6 (2): 29-37.

Wiedenheft BA (2006). Sulfolobus as a model organism for the study of diverse biological interests: Forays into thermal virology and oxidative stress Montana State Universit.

Yamazaki E, Inagaki M, Kurita O, Inoue T (2006). Antioxidant Activity of Japanese Pepper (Zanthoxylum piperitum DC.). Fruit. Food Chem., 100(1): 171-177.

Yang X ( 2008). Aroma constituents and alkylamides of red and green huaijiao (Zanthoxylum bungeanum and Zanthoxylum schinifolium). J Agric Food Chem. 56(5):1689-96.

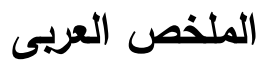

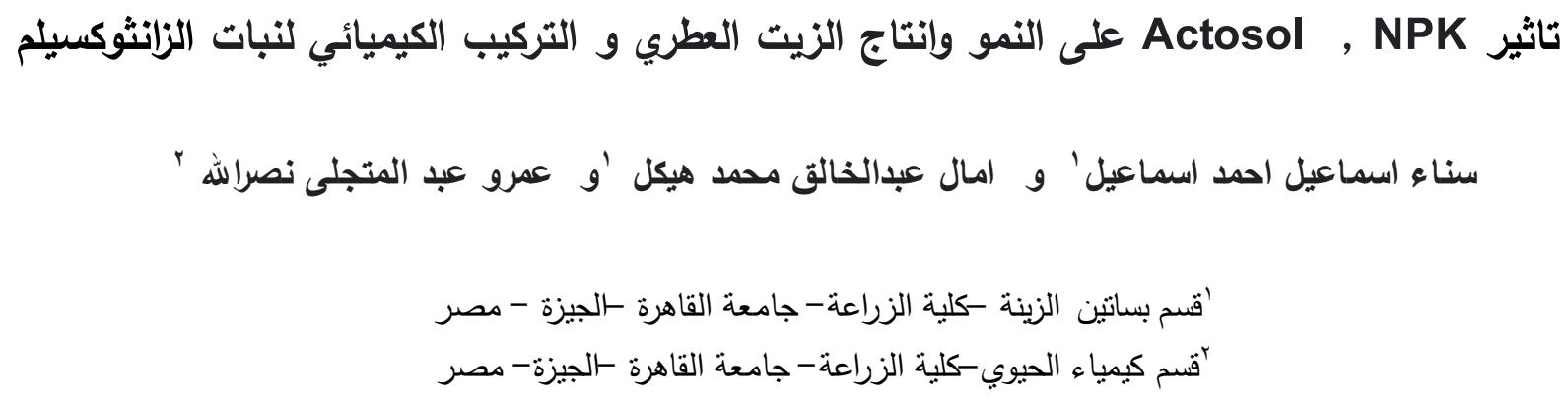

اجريت تجربة اصص علي نبات Zanthoxylum piperitum بهدف دراسة تاثيرالتشميد ب NPK والاكتوسول علي النمو الخضري ،و الزيت

الطيار ،والمحتوي الكيماوي ومضادات الاكسدة داخل الصوبة الساران بالمشتل التجريبى - قسم بسانين الزينة - كلية الزراعة -جامعة القاهرة-

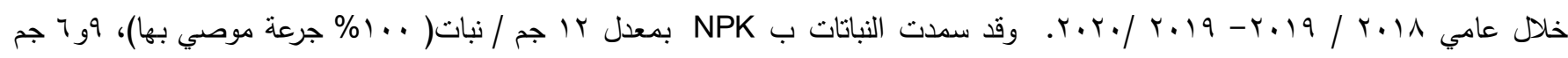

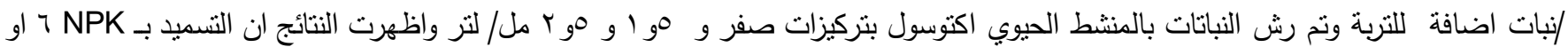
9 جم /نبات مع الرش بالاكتوسول هو r مل /لتر اعطي اطول النباتات مع اكبر عدد من الافرع علي النبات كما ادي الي زيادة الاوزان الطازجة

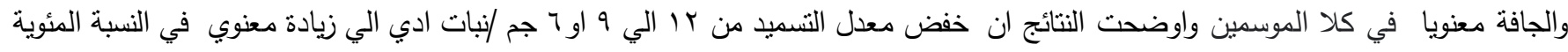

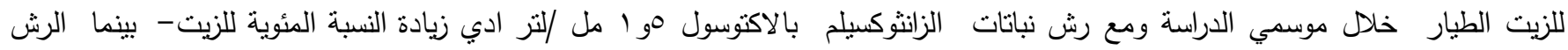

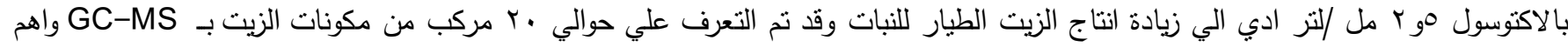

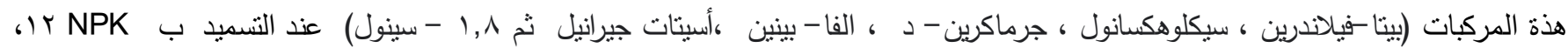

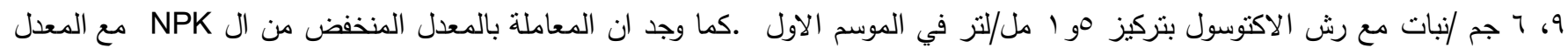

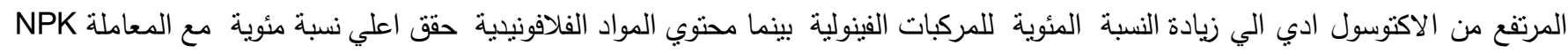

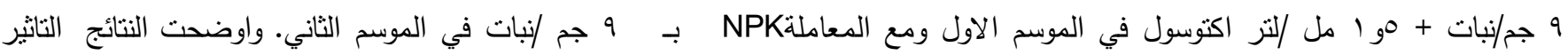

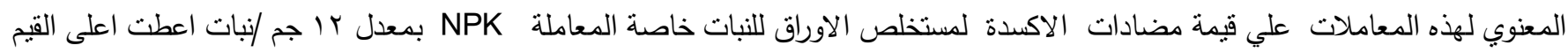
في الموسمين. 